\title{
Arte urbano, reflexión sobre lo repulsivo y el terror, y la necesidad patrimonial
}

\author{
María José Romero-Ternero I Antropóloga \\ URL de la contribución <www.iaph.es/revistaph/index.php/revistaph/article/view/4902>
}

El término patrimonio ya de por sí es complejo de definir, su tipología es variada: industrial, etnológico inmaterial, artístico, arqueológico, etc., también urbano. Es evidente que todo patrimonio cultural tiene presencia y se legitima en su sentido ideal y material (Godelier 1990; Smith 2006), de forma que no se puede desprender de la realidad si no es únicamente como abstracción. En todo caso, es imprescindible entender los usos del patrimonio (Smith 2006) y las diversas formas de musealizar los espacios (Macdonald 2012) porque ya no nos es de mucha utilidad, según las nuevas transformaciones culturales, el contenedor cerrado que era (y sigue siendo en muchos casos) "el museo".

En el transcurso temporal de la vida, por regla general el ser humano se ha identificado por su legado cultural. En este sentido, la condición humana declinará la conversión, sin ningún atisbo de menosprecio, de un bien cultural en patrimonio y el confiar su tutela al transcurso de su propia naturaleza. Algo tan sencillo como replantear la pregunta: ¿de dónde parte el término y la necesidad patrimonial? Sin embargo, como tal legado en lo que sí se convierte, al nacer, es en cultura. De ese modo, su razón de ser, a priori, no será otra que la de ser per se una naturaleza sui géneris, una herencia para transgredir o promocionar valores que no tiene por qué elevarse necesariamente a patrimonio y no por ello restarle valor.

De hecho así ocurre a través de las redes sociales con expresiones y manifestaciones artísticas y culturales que subrayan tanto la vulneración, el quebrantamiento, como el disfrute y lo lúdico. Con el arte urbano hablamos de un arte recursivo, dinámico y transformador. La transformación (Figueroa 2007) es tal, que los modos en cómo nos interrelacionamos, el impulso humano, está transgrediendo y haciéndose ver a través de nuevos cauces virtuales que se solapan con los espacios físicos para crear otros marcos que modifican "el orden establecido", marcos alterados que nos hacen ver más allá de nuestra propia realidad cotidiana.

Tras la lectura de uno de esos "marcos alterados", relatado por el artista malagueño Dreucol, a propósito de una de sus obras (Dávila 2020), hago una reflexión personal sobre lo repulsivo y el terror en el arte urbano. A modo ilustrativo lo vi también de forma clara en el arte urbano callejero presentado en una serie documental de cortometrajes en el canal Arte $^{1}$ en torno al nacimiento del grafiti y su evolución. Un arte urbano, legado cultural, que aunque no sea patrimonio en sí, genera en torno a él una subcultura, una filosofía y un modo de vida para un grupo social concreto. Un "patrimonio incómodo" que provocaba terror callejero, vandalismo y repulsión por su naturaleza incívica e indeseable, pero también inapelable en aquella época, desde los años 70 del siglo pasado, hasta su casi total desaparición.

La obra de Dreucol es una obra artística, virtual, clasificada como arte urbano, provocativa, en la que aparecen ciertas similitudes de atributos con obras célebres del género artístico de suspense y terror. La expresión artística de Dreucol (Dávila 2020) es tan repulsiva y grotesca como lo puede llegar a ser la de Tarantino, la de Alex de la Iglesia o la de Galder Gaztelu-Urrutia (El Hoyo, 2019) ¿Son obras de arte (relatos de ciencia ficción, arte audiovisual), con condiciones para convertirse en patrimonio (aunque incómodo para algunos), lo repulsivo y lo despreciable? ¿Acaso el relato de Dreucol no nos recuerda a aquel espacio radiofónico basado en la novela de Herbert George Wells, La guerra de los mundos, de 1898, donde se provocó una alarma social basada en la ficción? Según el National Geographic 
(Gavaldà 2019) 80 años más tarde todavía se considera uno de los momentos más grandes de la historia de la radio. Es un legado cultural dentro del género artístico de terror y ciencia ficción, que, sin ser patrimonio, no deja de provocarnos con su historia y relato literario.

Lo que sí intuimos, entre todos, es que estamos ante un paradigma que aclama a la complejidad, a la amplitud, a la apertura, a nodos espaciales entre lo físico y lo virtual (Coluccio 2019), que tiene como base la insistencia casi innata del ser humano a presentar controversias circunstanciales, a favor o en contra del arte y las expresiones artísticas, junto con valores de sostenibilidad, de cohesión, con proyectos conjuntos de cooperación y participación pública y privada. Por ello, se hace necesario llegar al público y expresar cuestiones de actualidad que atañen a todos, desde un punto de vista ecológico, y alcanzar el mayor número posible de soluciones a los problemas que nos planteamos.

A lo mejor sería cuestión de responder a ¿cuál es la funcionalidad del arte urbano? La idea es que, para convertirlo en patrimonio, no podemos dejar atrás el propósito de la practicidad y la utilidad, frente a lo contemplativo, como es el caso del muralista Alfaro Siqueiros (Ruiza, Fernández y Tamaro 2004), o el proyecto IMVG (Itinerario

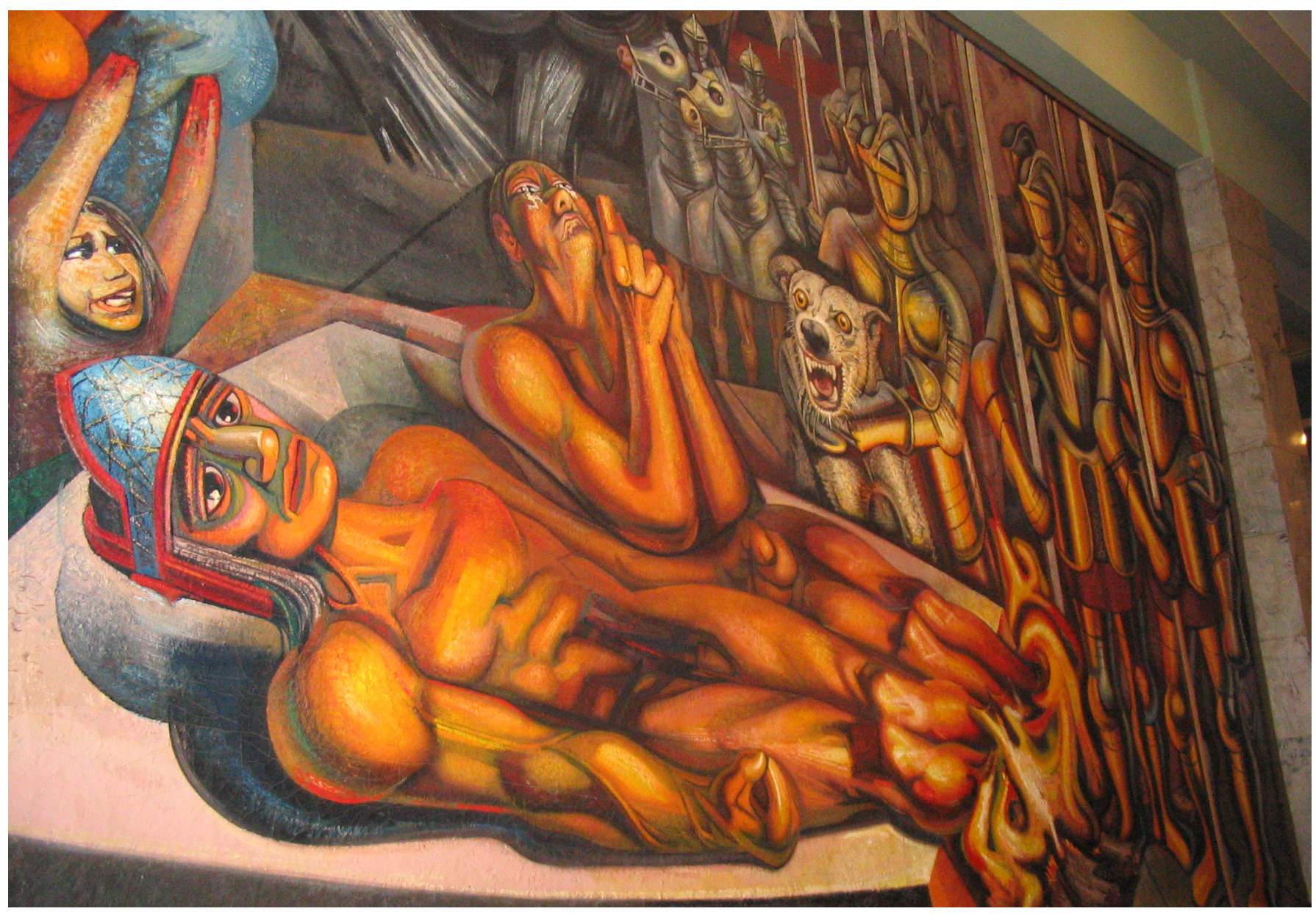

Tormento de Cuauhtémoc, mural de David Alfaro Siqueiros | foto Kate McCarthy 
Muralístico de Vitoria-Gasteiz) (Villajos, Werckmeister y García 2019) porque este tipo de arte concierne a la cuestión de la diversidad cultural. A las relaciones dialécticas entre el nos-otros. Todo forma parte de las inquietudes sociales, tarea que no empieza de vacío, sino desde una idiosincrasia, una simbología y unos valores culturales, y por tanto colmada de memoria colectiva. El arte urbano, sea como sea, patrimonio o no, necesita, mientras provoque reacción y simbolice valores y significados colectivos, de ese papel de la persona curadora o conservadora que lo promocione y lo active y lo gestione como legado cultural por sus diversos criterios, ya sean tecnológicos o antropológicos, o cualesquiera que se deseen preservar y que se erijan inapelables del momento.

\section{NOTAS}

1. Visionado en marzo 2021. Serie documental que narra la historia del grafiti desde los años 70 en Nueva York hasta su llegada a Europa una década más tarde.

\section{BIBLIOGRAFÍA}

- Coluccio, C.E. (2019) "Viral Mural", entre el muralismo y los espacios virtuales. Ge-Conservación, vol. 16, pp. 145-153. Disponible en: https://ge-iic.com/ojs/index.php/revista/article/ view/703 [Consulta: 01/04/2021]

- Dávila, R. (2020) Dreucol se 'salta' la cuarentena. La opinión de Málaga, 19 de abril de 2020. Disponible en: https://www. laopiniondemalaga.es/cultura-espectaculos/2020/04/19/ dreucol-salta-cuarentena-27574432.html [Consulta: 23/03/2021]

- Figueroa Saavedra, F. (2007) El graffiti en metálico: análisis sobre el graffiti y la circulación monetaria. Historia y comunicación social, vol. 12, pp. 23-44. Disponible en: https://revistas.ucm.es/index.php/HICS/article/view/ HICS0707110023A/19019 [Consulta: 23/03/2021]

- Gavaldà, J. (2019) La guerra de los mundos, la invasión de Marte que aterrorizó a América. Historia. National Geographic, 30 de octubre de 2019. Disponible en: https://historia. nationalgeographic.com.es/a/guerra-mundos-invasion-marteque-aterrorizo-a-america_14814 [Consulta: 23/03/2021]
- Godelier, M. (1990) Lo ideal y lo material: pensamiento, economías, sociedades (traducción de A.J. Desmont). Madrid: Taurus

- Kästner R. y Pedersen, L. (2017) The Rise of Graffiti Writing. Arte Tv. Disponible en: https://www.arte.tv/es/videos/ RC-015348/the-rise-of-graffiti-writing-temporada-1/ [Consulta: 01/04/2021]

- Macdonald, S. (2012) Nuevos pasos hacia el patrimonio transcultural. En: Díaz Balerdi, I. (coord.) Otras maneras de musealizar el patrimonio. Vitoria-Gasteiz: ARTIUM, pp. 79-98

- Romero-Ternero, M.J. (2017) Turismo y patrimonio etnológico aplicación dialógica al caso de procesos sobre dinamización ciudadana. Tesis doctoral inédita, Universidad de Sevilla

- Ruiza, M., Fernández, T. y Tamaro, E. (2004) Biografía de David Alfaro Siqueiros. En: Biografías y Vidas. La enciclopedia biográfica en línea. Barcelona. Disponible en: https://www. biografiasyvidas.com/biografia/s/siqueiros.htm [Consulta: 1/04/2021]

- Smith, L. (2006) Uses of Heritage. London: Routledge

- Villajos, S., Werckmeister, V. y García, L. (2019) Street Art and Intangible Heritage: a contextualising approach to public art in Vitoria-Gasteiz. Barcelona: Universitat de Barcelona 